\title{
Relations among Boron Status and Some Soil Properties of Isparta Region Apple Orchards
}

\author{
İbrahim ERDAL ${ }^{*}$, Ali COŞKAN¹, Zeliha KÜÇÜKYUMUK¹ ${ }^{1}$, Figen ERASLAN ${ }^{1}$ \\ ${ }^{1}$ Süleyman Demirel University, Faculty of Agriculture, Department of Soil Science and Plant Nutrition, 32260, \\ Isparta
}

(Alınış / Received: 16.05.2016, Kabul / Accepted: 28.09.2016, Online Yayınlanma / Published Online: 04.11.2016)

\begin{abstract}
Keywords
Apple

orchards,

Boron,

Isparta

Abstract: This study was conducted to determine the boron (B) status of apple orchards and examine the relations among B nutrition and some soil properties in Isparta province. For this purpose 250 gardens from the seven districts of the region were determined and soil and leaf samples were collected. In order to determine soil and leaf B status and relations among these some soil properties were determined. Similarly, other leaf nutrient concentrations were analyzed. According to the soil analysis it was seen that most of the soils are B-sufficient. If soil B concentrations were evaluated depending on the district, the lowest soil B $\left(0.26 \mathrm{mg} \mathrm{kg}^{-1}\right)$ was measured from the gardens of Senirkent, the highest B concentration $\left(3.44 \mathrm{mg} \mathrm{kg}^{-1}\right)$ was determined in Atabey. Looking at the individual districts, all apple orchards in Gönen and Keçiborlu have sufficient (0.5-2 mg kg-1) soil B. Also in Yalvaç, Atabey, Gelendost and Eğirdir 71\%, 95\%, 96\% and $97 \%$ of the soils had higher B concentration than B deficiency level $\left(0.5 \mathrm{mg} \mathrm{kg}^{-1}\right)$. The most soil B deficiency problem was observed in Senirkent and Yalvaç. Average soil B levels for Atabey, Eğirdir, Gelendost, Gönen, Keçiborlu, Senirkent and Yalvaç orchards were calculated as 1.32, 0.96, $0.87,0.67,0.91,0.49$ and $0.62, \mathrm{mg} \mathrm{kg}^{-1}$ respectively and general average were determined as 0.84 $\mathrm{mg} \mathrm{kg}^{-1}$. Depending on leaf analyze results, it was seen that $94.8 \%$ of the trees had sufficient B and only 5.2 percent of trees had B deficiency. According to the results, there is not B deficiency in $85 \%$ of the soils. And this reflects the leaf analysis as well. Although this result, there was not seen any correlation between soil and leaf B concentrations. But, there were negative correlations among available soil B and soil $\mathrm{pH}$ and Ca. Positive correlations were determined among soil B concentrations and other micro nutrients. While a negative correlation between leaf $\mathrm{B}$ concentration and leaf $\mathrm{P}$ was found, there was a positive correlation between $\mathrm{B}$ and $\mathrm{Mn}$.
\end{abstract}

\section{Isparta Yöresi Elma Bahçelerinin Bor Durumlarıyla Bazı Toprak Özellikleri Arasındaki İlişkiler}

Anahtar kelimeler Elma bahçeleri, Bor, Isparta
Özet: Bu çalışma, Isparta yöresi elma bahçelerinin bor (B) beslenme durumlarını belirlemek ve B beslenmesiyle bazı toprak özellikleri arasındaki ilişkileri incelemek amaçlanmıştır. Bu amaçla yedi bölgeden 250 bahçe belirlenerek toprak ve yaprak örnekleri alınmıştır. Toprak ve yaprakların B durumları belirlenerek bunlar arasındaki ve diğer bazı toprak özellikleri arasındaki ilişkiler belirlenmiştir. Benzer şekilde diğer yaprak besin elementi içerikleri de belirlenmiştir. Toprak analiz sonuçlarına göre, çoğu toprağın B seviyesinin yeterli olduğu görülmüştür. Bölgelere göre bir değerlendirme yapılırsa, en düşük B düzeyi $\left(0.26 \mathrm{mg} \mathrm{kg}^{-1}\right)$ Senirkent, en yüksek B düzeyi ise (3.44 mg kg-1) Atabeyde belirlenmiştir. Bölgelere bireysel olarak bakılırsa, Gönen ve Keçiborlu da ki bahçelerin tamamının B bakımından yeterli $\left(0.5-2 \mathrm{mg} \mathrm{kg}^{-1}\right)$ olduğu görülmektedir. Aynı zamanda, Yalvaç, Atabey, Gelendost ve Eğirdir bahçelerinin sırasıyla \% 71, \% 95, \% 96 ve \% 97' si nin eksiklik düzeyin $\left(0.5 \mathrm{mg} \mathrm{kg}^{-1}\right)$ üzerinde B içerdiği görülmüștür. En fazla B eksikliği sorununa Senirkent ve Yalvaç ta rastlanmıştır. Atabey, Eğirdir, Gelendost, Gönen, Keçiborlu, Senirkent ve Yalvaç için ortalama toprak B düzeyleri sırasıyla $1.32,0.96,0.87,0.67,0.91,0.49$ ve $0.62, \mathrm{mg} \mathrm{kg}^{-1}$ olarak belirlenirken genel ortalama $0.84 \mathrm{mg} \mathrm{kg}^{-1}$ olarak hesaplanmıştır. Yaprak analizlerine göre ağaçların $\%$ 94.8' i B bakımından yeterli, sadece \% 5,2lik kısmının yetersiz olduğu görülmüştür. Bu sonuçlara göre toprakların \% 85'in de B eksikliğine rastlanmamakta ve bu durum yaprak analizlerinde de görülmektedir. Bu sonuçlara rağmen toprak ve yaprak analiz sonuçları arasında bir korelasyon görülmemiştir. Fakat toprak B konsantrasyonuyla toprak pH sı ve Ca arasında negatif ilişkiler belirlenmiştir. Toprak B konsantrasyonuyla diğer mikro elementler arasında pozitif ilişkiler görülmüştür. Yaprak B konsantrasyonuyla yaprak P konsantrasyonu arasında negatif, B ile Mn arasında ise pozitif ilişkiler belirlenmiştir. 


\section{Introduction}

Boron is one of the important nutrients playing role on sugar transport, cell wall synthesis, carbohydrate metabolism, RNA metabolism, respiration, IAA metabolism, phenol metabolism and etc. Because of many roles of boron on plant physiology, B deficiency can occur as different deficiency symptoms. Because $\mathrm{B}$ is a phloem immobile nutrient, B deficiency can result in numerous fruit disorders affecting fruit storability and quality. If a plant has B deficiency, cell wall structure damage and denaturing, cracking, decaying and softening can arise in the some fruits and tuber crops [1,2]. It is known that apple trees require higher amount of $B$ [3]. Boron is required for pollen germination and pollen tube growth resulting in fruit setting. Therefore, B fertilization may increase yield, particularly when plants are grown on sandy soil with a low content of available B. Although all mechanism of the $B$ has not been well understood, the effect of $B$ fertilization of apple trees on fruit quality can change with the several biological and environmental factors such as cultivar, orchard location, rainfall, air temperature has been well known for many years. Both low and excessive concentration of $B$ in apple trees cause poor fruit quality. Apples with a low B concentration have a short storage life because of the high susceptibility to a break down. On the other hand, high $B$ concentration in apples enhances the incidence of internal disorders, particularly water core and internal breakdown. Also, high B concentration in apples could result in increased decay and decreased fruit firmness $[1,4]$.
Boron uptake of the plants is in close relation with some soil, plant and environment factors. Even plants grown on a same soil there can have different characteristics for B using ability [5, 6]. Boron uptake by plants decreases with the increase of $\mathrm{pH}$ and lime [7]. Soil texture and clay type are other factors effecting plant $B$ nutrition and it is recorded that plants can uptake better B from the coarse texture soils [8]. In regions having more rainfall, coarse texture with low organic matter containing soils don't have sufficient B. But increasing of organic matter in these soils contributes B nutrition of plants [9].

In plant production, yield and quality have close relation with plant mineral nutrient concentrations. So it is required to know sufficient levels of nutrients for desired production. Boron is a nutrient that deficiency and toxicity levels are close in the soils So, keeping the sufficient amount of soil B concentration needs close monitoring.

Soil and leaf analysis are used very often to determine nutritional status of plants and soils fertility status $[1,10,11,12,13,14,15,16,17,18]$. Nutrient amounts determined with these analyses compare with previously determined standard values. Even sometimes these results completely not meet expected results; these analysis methods are the most trustable ways for determining nutritional status of plants and soils. In this study, it was aimed to investigate the nutritional status of apple orchards in Isparta district.

Table 1. Sampling areas

\begin{tabular}{cccc}
\hline Districts & $\begin{array}{c}\text { Rates in the total apple planted areas in } \\
\text { Isparta (\%) }\end{array}$ & $\begin{array}{c}\text { The number of the } \\
\text { sample }\end{array}$ & $\begin{array}{c}\text { Distribution in the total sample } \\
(\%)\end{array}$ \\
\hline Atabey & 2.2 & 20 & 8.0 \\
Eğirdir & 24.9 & 62 & 24.8 \\
Gelendost & 24.4 & 71 & 28.4 \\
Gönen & 4.0 & 14 & 5.6 \\
Keçiborlu & 1.0 & 12 & 4.8 \\
Senirkent & 18.0 & 21 & 8.4 \\
Yalvaç & 11.6 & 50 & 20.0 \\
\hline TOTAL & 86.1 & 250 & 100.0 \\
\hline
\end{tabular}

Table 2. Soil pH, EC, $\mathrm{OM}$ and $\mathrm{CaCO}_{3}$ status of apple orchards

\begin{tabular}{lcccccccccccc}
\hline & \multicolumn{3}{c}{$\mathrm{pH}$} & \multicolumn{4}{c}{$\mathrm{EC}\left(\mathrm{dS} \mathrm{m}{ }^{-1}\right)$} & \multicolumn{3}{c}{ O.M $(\%)$} & \multicolumn{3}{c}{$\mathrm{CaCO}_{3}(\%)$} \\
\hline Districts & Min. & Max. & Mean & Min. & Max. & Mean & Min. & Max. & Mean & Min. & Max. & Mean \\
\hline Atabey & 7.20 & 7.78 & 7.55 & 0.18 & 0.68 & 0.32 & 0.8 & 5.7 & 3.0 & 1.0 & 21 & 9.9 \\
Eğirdir & 6.80 & 7.82 & 7.47 & 0.13 & 0.55 & 0.23 & 0.6 & 6.5 & 2.9 & 1.0 & 46 & 8.6 \\
Gelendost & 7.24 & 8.07 & 7.69 & 0.17 & 0.68 & 0.28 & 0.5 & 5.8 & 2.3 & 1.0 & 50 & 17.4 \\
Gönen & 7.49 & 7.99 & 7.77 & 0.21 & 0.71 & 0.35 & 1.0 & 1.7 & 1.4 & 34 & 46 & 41.0 \\
Keçiborlu & 7.69 & 8.02 & 7.85 & 0.22 & 0.54 & 0.34 & 1.4 & 2.5 & 1.8 & 27 & 39 & 32.0 \\
Senirkent & 7.58 & 8.05 & 7.78 & 0.19 & 0.72 & 0.30 & 0.8 & 3.4 & 2.1 & 9.0 & 45 & 30.0 \\
Yalvaç & 7.39 & 8.26 & 7.82 & 0.15 & 0.83 & 0.24 & 0.6 & 4.4 & 2.4 & 8.0 & 46 & 30.0 \\
\hline Mean & & 7.71 & \multicolumn{1}{c}{0.29} & & & 2.3 & & 24 & 24 \\
\hline
\end{tabular}




\section{Materials and Methods}

Study was carried on 250 apple gardens. For this, 7 districts, where intensive apple growing are made, were determined and gardens were tried to be chosen according to production area for each district (Table 1). From these gardens soils $(0-30 \mathrm{~cm})$ and leaf samples were taken and brought to the lab and prepared for the analysis as described by Kacar [19] and Jones et al. [10] .
Table 3. Soil B variations for individual districts

\begin{tabular}{llll}
\hline \multirow{2}{*}{ Districts } & \multicolumn{3}{c}{$\mathrm{B}\left(\mathrm{mg} \mathrm{kg}^{-1}\right)$} \\
\cline { 2 - 4 } & Min. & Max. & Mean \\
\hline Atabey & 0.39 & 3.44 & 1.32 \\
Eğirdir & 0.32 & 2.49 & 0.96 \\
Gelendost & 0.39 & 2.51 & 0.87 \\
Gönen & 0.54 & 0.85 & 0.67 \\
Keçiborlu & 0.65 & 1.23 & 0.94 \\
Senirkent & 0.26 & 0.88 & 0.49 \\
Yalvaç & 0.19 & 2.08 & 0.62 \\
\hline Mean & & & 0.84 \\
\hline
\end{tabular}

Table 4. Soil $\mathrm{Fe}, \mathrm{Cu}, \mathrm{Zn}, \mathrm{Mn}, \mathrm{Ca}, \mathrm{Mg}, \mathrm{K}$ and $\mathrm{P}$ variations for individual districts ( $\mathrm{mg} \mathrm{kg}^{-1}$ )

\begin{tabular}{|c|c|c|c|c|c|c|c|c|c|c|c|c|}
\hline \multirow{2}{*}{ Districts } & \multicolumn{3}{|c|}{$\mathrm{Fe}$} & \multicolumn{3}{|c|}{$\mathrm{Cu}$} & \multicolumn{3}{|c|}{$\mathrm{Zn}$} & \multicolumn{3}{|c|}{$\mathrm{Mn}$} \\
\hline & Min. & Max. & Mean & Min. & Max. & Mean & Min. & Max. & Mean & Min. & Max. & Mean \\
\hline Atabey & 2.10 & 4.23 & 3.0 & 2.10 & 4.23 & 3.0 & 2.10 & 4.23 & 3.0 & Min & Max & Ort. \\
\hline Eğirdir & 1.24 & 19.21 & 7.3 & 1.24 & 19.21 & 7.3 & 1.24 & 19.21 & 7.3 & 1.84 & 7.0 & 4.0 \\
\hline Gelendost & 2.48 & 9.35 & 4.1 & 2.48 & 9.35 & 4.1 & 2.48 & 9.35 & 4.1 & 0.98 & 11.71 & 6.8 \\
\hline Gönen & 0.72 & 3.11 & 1.9 & 0.72 & 3.11 & 1.9 & 0.72 & 3.11 & 1.9 & 2.98 & 12.8 & 6.6 \\
\hline Keçiborlu & 0.88 & 3.04 & 1.7 & 0.88 & 3.04 & 1.7 & 0.88 & 3.04 & 1.7 & 0.6 & 4.6 & 2.1 \\
\hline Senirkent & 1.83 & 4.17 & 2.8 & 1.83 & 4.17 & 2.8 & 1.83 & 4.17 & 2.8 & 0.8 & 5.9 & 2.1 \\
\hline \multirow[t]{3}{*}{ Yalvaç } & 0.89 & 5.38 & 2.7 & 0.89 & 5.38 & 2.7 & 0.89 & 5.38 & 2.7 & 1.5 & 9.2 & 4.6 \\
\hline & \multicolumn{3}{|c|}{$\mathrm{Ca}$} & \multicolumn{3}{|c|}{$\mathrm{Mg}$} & \multicolumn{3}{|c|}{$\mathrm{K}$} & \multicolumn{3}{|c|}{$\mathrm{P}$} \\
\hline & Min. & Max. & Mean & Min. & Max. & Mean & Min. & Max. & Mean & Min. & Max. & Mean \\
\hline Atabey & 2429 & 7257 & 4656 & 214 & 838 & 569 & 186 & 1403 & 763 & 17.2 & 103.5 & 60.6 \\
\hline Eğirdir & 2086 & 8039 & 5102 & 161 & 1011 & 513 & 42 & 962 & 391 & 1.69 & 91.26 & 38.2 \\
\hline Gelendost & 2408 & 9210 & 5505 & 134 & 1105 & 456 & 143 & 2085 & 559 & 0.56 & 104.4 & 33.8 \\
\hline Gönen & 3984 & 6018 & 4792 & 239 & 936 & 394 & 195 & 1487 & 466 & 10.6 & 59.3 & 37.7 \\
\hline Keçiborlu & 3848 & 7359 & 5082 & 347 & 1029 & 749 & 370 & 1300 & 728 & 0.28 & 65.9 & 33.4 \\
\hline Senirkent & 4000 & 8364 & 5680 & 354 & 907 & 573 & 177 & 7316 & 1361 & 0.7 & 84.2 & 33.6 \\
\hline Yalvaç & 4507 & 12884 & 6995 & 119 & 900 & 449 & 158 & 1124 & 482 & 0.28 & 89.4 & 21.2 \\
\hline
\end{tabular}

Table 5. Evaluation of the soils in terms of available nutrients

\begin{tabular}{|c|c|c|c|c|c|c|c|c|c|}
\hline Nutrients & $\begin{array}{l}\text { Levels } \\
\left(\mathrm{mg} \mathrm{kg}^{-1}\right)\end{array}$ & Evaluation & $\begin{array}{l}\text { Number } \\
\text { of the } \\
\text { samples }\end{array}$ & $\begin{array}{l}\text { Distribution } \\
(\%)\end{array}$ & Nutrients & $\begin{array}{l}\text { Levels } \\
\left(\mathrm{mg} \mathrm{kg}^{-1}\right)\end{array}$ & Evaluation & $\begin{array}{l}\text { Number of } \\
\text { the samples }\end{array}$ & $\begin{array}{l}\text { Distribution } \\
(\%)\end{array}$ \\
\hline \multirow{5}{*}{$\mathbf{P}$} & $0-5$ & Very low & 20 & 8.0 & \multirow{4}{*}{ B } & $<0.5$ & Low & 37 & 14.8 \\
\hline & $5-10$ & Low & 18 & 7.2 & & $0.5-2.00$ & Enough & 206 & 82.4 \\
\hline & $10-15$ & Medium & 20 & 8.0 & & $2.0-5.0$ & High & 7 & 2.8 \\
\hline & $15-20$ & High & 23 & 9.2 & & $>5.0$ & Very high & 0 & 0 \\
\hline & $>20$ & Very high & 169 & 67.6 & \multirow{3}{*}{$\mathbf{F e}$} & $<2.5$ & Low & 60 & 24 \\
\hline \multirow{5}{*}{$\mathbf{K}$} & $<50$ & Very low & 1 & 0.4 & & $2.5-4.5$ & $\begin{array}{l}\text { Deficiency } \\
\text { can arise }\end{array}$ & 128 & 51 \\
\hline & $50-100$ & Low & 2 & 0.8 & & $>4.5$ & Enough & 62 & 25 \\
\hline & $100-300$ & Medium & 60 & 24 & \multirow{3}{*}{$\mathrm{Cu}$} & $0.2-0.25$ & Medium & 2 & 0.8 \\
\hline & $300-1000$ & Good & 169 & 67.6 & & $0.26-1.0$ & Enough & 5 & 2 \\
\hline & $>1000$ & Over & 18 & 7.2 & & $>1$ & High & 243 & 97.2 \\
\hline \multirow{5}{*}{ Ca } & $<380$ & Very low & 0 & 0.0 & \multirow{5}{*}{ Zn } & $<0.2$ & Very low & 0 & 0 \\
\hline & $380-1150$ & Low & 0 & 0.0 & & $0.2-0.7$ & Low & 73 & 29 \\
\hline & $\begin{array}{l}1150- \\
3500\end{array}$ & Medium & 14 & 5.6 & & $0.7-2.4$ & Medium & 126 & 51 \\
\hline & $\begin{array}{l}3500- \\
10000\end{array}$ & High & 234 & 93.6 & & $>2.4$ & High & 51 & 20 \\
\hline & $>10000$ & Very high & 2 & 0.8 & & & & & \\
\hline \multirow{5}{*}{ Mg } & $<50$ & Very low & 0 & 0 & \multirow{5}{*}{ Mn } & $<0.2$ & Very low & 0 & 0.0 \\
\hline & $50-160$ & Low & 2 & 0.8 & & $0.2-0.7$ & Low & 2 & 1 \\
\hline & $160-480$ & Medium & 130 & 52 & & $0.7-5$ & Medium & 123 & 49 \\
\hline & $480-1500$ & High & 118 & 47.2 & & & & & \\
\hline & $>1500$ & Very high & 0 & 0 & & $>5$ & High & 125 & 50 \\
\hline
\end{tabular}


Table 6. Leaf B variations for individual districts

\begin{tabular}{llll}
\hline \multirow{2}{*}{ Districts } & \multicolumn{3}{c}{$\mathrm{B}\left(\mathrm{mg} \mathrm{kg}^{-1}\right)$} \\
\cline { 2 - 4 } & Min. & Max & Means \\
\hline Atabey & 31 & 51 & 38.9 \\
Eğirdir & 26 & 44 & 33.1 \\
Gelendost & 21 & 58 & 32.3 \\
Gönen & 10 & 51 & 33.2 \\
Keçiborlu & 29 & 43 & 36.5 \\
Senirkent & 21 & 46 & 32.2 \\
Yalvaç & 20 & 51 & 29.6 \\
\hline Mean & & & 33.7 \\
\hline
\end{tabular}

To determine soil available nutrients, $\mathrm{P}$ extracted with $\mathrm{NaHCO}_{3}[20], \mathrm{K}, \mathrm{Ca}$, and $\mathrm{Mg}$ extracted with $\mathrm{NH}_{4} \mathrm{AOC}[21]$ and $\mathrm{Mn}, \mathrm{Zn}, \mathrm{Fe}$, and $\mathrm{Cu}$ extracted with DTPA [22]. Phosphorus measurement was done using spectrophotometer; others were measured with Atomic Absorption Spectrophotometer. Soil texture was determined using hydrometer [23] and $\mathrm{CaCO}_{3}$ content was measured with calcimeter [24]. Soil organic matter was determined based on Walkley and Black [25]. Soil pH was measured using pH mater in suspension of soil and water at the rates of $1 / 2.5$.

In order to determine soil extractable B, $20 \mathrm{~g}$ of soil was weighted in to $250 \mathrm{ml}$ flask and $40 \mathrm{ml}$ of $0,01 \mathrm{M}$ $\mathrm{CaCl}_{2}$ solution was added. Suspension was boiled for
5 minutes using re-circulated cooling system. Then solution was cooled until room temperature and filtrated through the blue band filter paper. Boron concentration of filtrate was measured with ICP [19].

For leaf analysis, samples were dried at $65 \pm 5^{\circ} \mathrm{C}$ and were grounded. Afterwards, samples were wet digested with microwave oven and filled up to $50 \mathrm{ml}$ with ultra-pure water. Total nitrogen was analyzed according to Kjeldahl method. Phosphorus concentrations of samples were determined with a spectrophotometer (Shimadzu UV-1208) at $430 \mathrm{~nm}$ according to the vanadomolybdo phosphoric acid method. Potassium, $\mathrm{Ca}, \mathrm{Mg}, \mathrm{Fe}, \mathrm{Cu}, \mathrm{Zn}$, and $\mathrm{Mn}$ concentrations were determined using atomic absorption spectrophotometer. Boron concentration of the leaf was measured using the same filtrate with ICP [26].

For evaluating soil B level, $0.5 \mathrm{mg} \mathrm{B} \mathrm{kg}^{-1}$ was accepted as critical concentration [27]. Sufficient leaf B concentration was accepted as $25-40 \mathrm{mg} \mathrm{kg}^{-1}$ [10]. Other classifications were made using the classification chard given in Alpaslan et al., [28]. for the soils and given in Jones et al. [10] for he leaves.

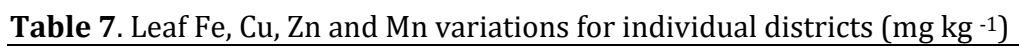

\begin{tabular}{lcrrrrrrrrrrr}
\hline & \multicolumn{3}{c}{ Fe } & \multicolumn{4}{c}{ Cu } & \multicolumn{3}{c}{ Zn } & \multicolumn{3}{c}{ Mn } \\
\hline Districts & Min. & \multicolumn{1}{c}{ Max. } & Mean & Min. & \multicolumn{1}{c}{ Max. } & Mean & \multicolumn{1}{c}{ Min. } & Max. & Mean & Min. & Max. & Mean \\
\hline Atabey & 94.1 & 203.0 & 135.0 & 1.4 & 11.4 & 5.6 & 27.3 & 115.2 & 49.3 & 44.4 & 137.0 & 85.7 \\
Eğirdir & 50.8 & 205.5 & 119.2 & 2.9 & 19.6 & 10.3 & 17.6 & 158.7 & 55.6 & 21.3 & 254.1 & 85.1 \\
Gelendost & 23.8 & 280.3 & 68.0 & 0.4 & 12.3 & 4.9 & 7.0 & 129.4 & 35.3 & 18.3 & 122.3 & 59.3 \\
Gönen & 27.6 & 161.8 & 65.5 & 5.4 & 11.0 & 7.9 & 10.9 & 57.8 & 21.1 & 68.1 & 150.0 & 107.4 \\
Keçiborlu & 43.4 & 83.4 & 60.7 & 7.4 & 12.8 & 9.7 & 6.3 & 28.1 & 12.3 & 101.8 & 279.9 & 180.0 \\
Senirkent & 27.9 & 151.6 & 78.7 & 8.5 & 33.1 & 13.0 & 5.9 & 77.5 & 21.6 & 60.3 & 243.8 & 103.2 \\
Yalvaç & 22.1 & 136.1 & 71.9 & 2.5 & 236.8 & 13.5 & 5.4 & 46.4 & 18.0 & & & \\
\hline
\end{tabular}

Table 8. Leaf $\mathrm{P}, \mathrm{K}, \mathrm{Ca}, \mathrm{Mg}$ and $\mathrm{N}$ variations for individual districts (\%)

\begin{tabular}{llllllllll}
\hline \multicolumn{1}{l}{} & $\mathrm{P}$ & \multicolumn{3}{c}{$\mathrm{K}$} & \multicolumn{3}{c}{ Ca } \\
\hline Districts & Min. & Max. & Mean & Min. & Max. & Mean & Min. & Max. & Mean \\
\hline Atabey & 0.11 & 0.28 & 0.17 & 1.24 & 2.29 & 1.78 & 0.47 & 1.08 & 0.84 \\
Eğirdir & 0.12 & 0.31 & 0.19 & 0.79 & 3.15 & 1.80 & 0.44 & 1.98 & 0.89 \\
Gelendost & 0.05 & 0.47 & 0.21 & 0.81 & 3.63 & 1.80 & 0.67 & 1.97 & 1.22 \\
Gönen & 0.11 & 0.29 & 0.15 & 1.18 & 2.45 & 1.74 & 1.02 & 2.17 & 1.38 \\
Keçiborlu & 0.09 & 0.22 & 0.12 & 1.18 & 3.89 & 2.21 & 0.97 & 2.24 & 1.44 \\
Senirkent & 0.12 & 0.32 & 0.18 & 1.29 & 3.47 & 2.06 & 1.23 & 2.40 & 1.60 \\
Yalvaç & 0.13 & 0.33 & 0.20 & 1.16 & 2.98 & 1.88 & 0.73 & 2.36 & 1.21 \\
\hline & Mg & & & N & & & & & \\
Districts & Min. & Max. & Mean & Min. & Max. & Mean & & & \\
Atabey & 0.25 & 0.42 & 0.35 & 1.7 & 3.0 & 2.5 & & & \\
Eğirdir & 0.24 & 0.75 & 0.37 & 1.7 & 3.0 & 2.5 & & & \\
Gelendost & 0.23 & 0.64 & 0.39 & 1.7 & 3.2 & 2.5 & & & \\
Gönen & 0.36 & 0.61 & 0.44 & 1.4 & 2.6 & 2.2 & & & \\
Keçiborlu & 0.34 & 1.22 & 0.71 & 1.4 & 2.2 & 1.86 & & & \\
Senirkent & 0.31 & 0.72 & 0.46 & 1.7 & 2.8 & 2.3 & & & \\
Yalvaç & 0.20 & 0.81 & 0.36 & 1.8 & 3.1 & 2.4 & & &
\end{tabular}


Table 9. Evaluation of the leaf nutrient concentrations

\begin{tabular}{|c|c|c|c|c|}
\hline Nutrients & Levels & Evaluation & $\begin{array}{l}\text { Number of the } \\
\text { samples }\end{array}$ & $\begin{array}{l}\text { Distribution } \\
(\%)\end{array}$ \\
\hline \multirow{3}{*}{$P, \%$} & $<0.15$ & Low & 36 & 14.4 \\
\hline & $0.15-0.30$ & Enough & 214 & 85.6 \\
\hline & $>0.30$ & High & 0 & 0 \\
\hline \multirow{3}{*}{$\mathrm{K}, \%$} & $<1.0$ & Low & 3 & 1.2 \\
\hline & $1.0-1.6$ & Enough & 69 & 27.6 \\
\hline & $>1.6$ & High & 178 & 71.2 \\
\hline \multirow{3}{*}{$\mathrm{Ca}, \%$} & $<1.2$ & Low & 139 & 55.6 \\
\hline & $1.2-2.0$ & Enough & 107 & 42.8 \\
\hline & $>2.0$ & High & 4 & 1.6 \\
\hline \multirow{3}{*}{$\mathrm{Mg}, \%$} & $<0.20$ & Low & 0 & 0 \\
\hline & $0.20-0.40$ & Enough & 165 & 66 \\
\hline & $>0.40$ & High & 85 & 34 \\
\hline \multirow{3}{*}{$\mathrm{N}, \%$} & $<2$ & Low & 18 & 7.2 \\
\hline & $2-3$ & Enough & 230 & 92 \\
\hline & $>3$ & High & 2 & 0.8 \\
\hline \multirow{3}{*}{$\mathrm{B}, \mathrm{mg} \mathrm{kg}^{-1}$} & $<25$ & Low & 13 & 5.2 \\
\hline & $25-40$ & Enough & 214 & 85.6 \\
\hline & $>40$ & High & 23 & 9.2 \\
\hline \multirow{3}{*}{$\mathrm{Fe}, \mathrm{mg} \mathrm{kg}^{-1}$} & $<50$ & Low & 60 & 24 \\
\hline & $50-100$ & Enough & 104 & 41.6 \\
\hline & $>100$ & High & 86 & 34.4 \\
\hline \multirow{3}{*}{$\mathrm{Cu}, \mathrm{mg} \mathrm{kg}^{-1}$} & $<6$ & Low & 51 & 20.4 \\
\hline & $6-20$ & Enough & 196 & 78.4 \\
\hline & $>20$ & High & 3 & 1.2 \\
\hline \multirow{3}{*}{$\mathrm{Zn}, \mathrm{mg} \mathrm{kg}^{-1}$} & $<20$ & Low & 91 & 36.4 \\
\hline & $20-50$ & Enough & 115 & 46 \\
\hline & $>50$ & High & 44 & 17.6 \\
\hline \multirow{3}{*}{ Mn, mg kg-1 } & $<30$ & Low & 9 & 3.6 \\
\hline & $30-100$ & Enough & 174 & 69.6 \\
\hline & $>100$ & High & 67 & 26.8 \\
\hline
\end{tabular}

\section{Results and Discussion}

\subsection{Soil analysis}

There is not salinity (EC) problem of the apple orchards and $\mathrm{pH}$ of the soils was between 6.80 and 8.26. Lime and organic matter (OM) content of the soils showed wide variation between $1-59 \%$ and $0.5-$ $6.5 \%$ respectively. Mean values of $\mathrm{pH}, \mathrm{EC}, \mathrm{OM}$ and $\mathrm{CaCO}_{3}$ was calculated as $7.710 .29 \mathrm{ds} \mathrm{m}^{-1}, 2.3 \%$ and $24 \%$ respectively (Table 2 ).

If an evaluation was made for each district, the lowest B concentration in the soils was determined in Yalvaç, the highest was determined in Atabey district (Table 2). According to the average values of each district for Atabey, Eğirdir, Gelendost, Gönen, Keçiborlu, Senirkent and Yalvaç, B levels of districts was 1.32, 0.96, 0.87, $0.67,0.94,0.49$ and $0.62 \mathrm{mgkg}^{-1}$ respectively. The general mean $\mathrm{B}$ value of the all areas was calculated as $0.84 \mathrm{mgkg}^{-1}$ (Table 3). The other available nutrient variations for each district are given in Table 4. Plant available nutrient concentrations and their evaluations were given in Table 5. As indicated there, all of soils for $\mathrm{Ca}$ and most of the soil for $\mathrm{P}, \mathrm{K}, \mathrm{Mg}, \mathrm{Mn}$ and $\mathrm{Cu}$ are sufficient [28]. Also about $85 \%$ of the soils are sufficient for available B, $15 \%$ of the soil is Bdeficient [27]. These results represent the $85 \%$ of the total apple growing area in Isparta region [29].

\subsection{Plant analysis}

Boron variations of the apple orchards in each district were given in Table 6. As seen there, while the lowest B concentration was determined in Gönen, the highest was determined in Gelendost orchards. An average B concentration for all orchards was calculated as $33.7 \mathrm{mg} \mathrm{kg}^{-1}$. Variation of leaf $\mathrm{Fe}, \mathrm{Cu}, \mathrm{Zn}$ and $\mathrm{Mn}$ concentrations were 22.1-280.3, 0.4-236.8, 5.4-158.7 ve $18.3-279.9 \mathrm{mg} \mathrm{kg}^{-1}$ and the means of them were $87.7,9.1,35.0$ ve $82.7 \mathrm{mg} \mathrm{kg}^{-1}$ respectively (Table 7). Leaf macronutrient concentrations of the orchards varied between $0.05-0.47 \%$ for $\mathrm{P}, 0.79$ $3.89 \%$ for $\mathrm{K}, 0.44-2.4 \%$ for $\mathrm{Ca}, 0.20-1.22 \%$ for $\mathrm{Mg}$ and $1.4-3.2 \%$ for $\mathrm{N}$ with the means of same orders $0.19 \%$, $1.86 \%, 16 \%, 0.40 \%$ and $2.42 \%$ (Table 8 ). Looking at the all nutrient values from the all orchards it was seen that only $5.2 \%$ of the orchards had B deficiency while the rest had sufficient and high. However, 24\% $20.4 \%, 36.4 \%$ and $3.6 \%$ of the orchard had $\mathrm{Fe}, \mathrm{Cu}, \mathrm{Zn}$ and $\mathrm{Mn}$ deficiency, respectively. At the same time all orchards are rich for $\mathrm{Mg}$, and $85,6 \%$ for $\mathrm{P}, 98,8 \%$ for 
Table 10. Correlations among some soil properties and soil and leaf B concentrations

Soil properties

\begin{tabular}{ccccccccccccc}
\hline & $\mathrm{pH}$ & $\mathrm{EC}$ & $\mathrm{OM}$ & $\mathrm{CaCO}^{3}$ & $\mathrm{Fe}$ & $\mathrm{Cu}$ & $\mathrm{Zn}$ & $\mathrm{Mn}$ & $\mathrm{Ca}$ & $\mathrm{Mg}$ & $\mathrm{P}$ & $\mathrm{Mg}$ \\
\hline Soil B & $-0.49^{* * *}$ & $\mathrm{~ns}$ & $0.35^{* * *}$ & $-0.18^{* *}$ & $0.38^{* * *}$ & $0.36^{* * *}$ & $0.19^{* *}$ & $0.24^{* * *}$ & $-0.32^{* * *}$ & $0.17^{* *}$ & $\mathrm{~ns}$ & $\mathrm{~ns}$ \\
\hline Leaf B & $\mathrm{ns}$ & $\mathrm{ns}$ & $\mathrm{ns}$ & $\mathrm{ns}$ & $\mathrm{ns}$ & $\mathrm{ns}$ & $\mathrm{ns}$ & $\mathrm{ns}$ & $\mathrm{ns}$ & $\mathrm{ns}$ & $\mathrm{ns}$ & $\mathrm{ns}$ \\
\hline **: $\mathrm{p}<0.05,{ }^{* * *} \mathrm{p}<0.001, \mathrm{~ns}$ & non-significant & & & & & & & & & &
\end{tabular}

$\mathrm{K}$ and $92,8 \%$ for $\mathrm{N}$ are sufficient. The highest nutritional problem was seen in terms of Ca and it was seen that $55,6 \%$ of the trees has Ca deficiency $[1$, 10] (Table 9).

\subsection{Relations of $B$ analysis results with the other factors}

According to the results obtained there is a significant $(\mathrm{p}<0.001)$ relation between soil and leaf $B$ concentrations (Figure 1). Looking at the soil B levels and other soil factors there are negative correlations between B-pH, B-Ca and B- $\mathrm{CaCO}^{3}$. Positive correlations between soil $\mathrm{B}$ and other micronutrient were found and this can be expressed that B and Fe, $\mathrm{Cu}, \mathrm{Zn}$ and $\mathrm{Mn}$ are being affected from the same soil conditions [1, 2, 30]. There were not any correlations among leaf $\mathrm{B}$ concentration and other parameters (Table 10).

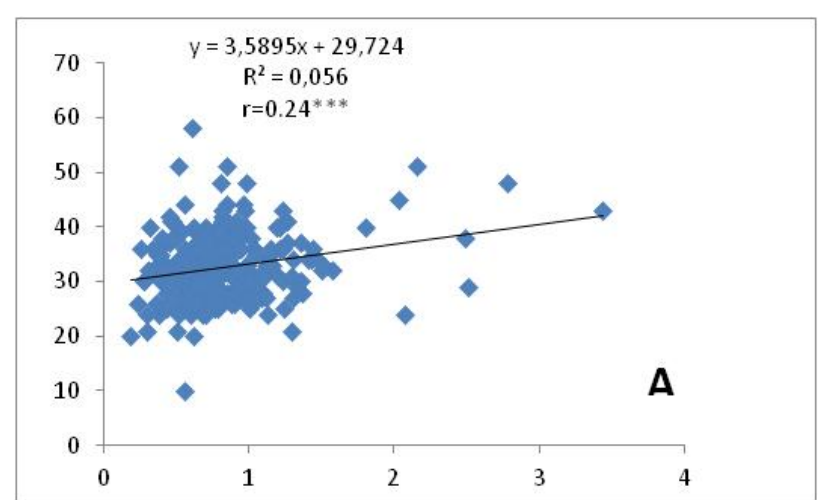

Figure 1. Correlations between soil and leaf B concentration

\section{Acknowledgment}

We thanks to National Boron Institute (BOREN) for supporting this work as a research project

\section{References}

[1] Bergmann W. 1992. Nutritional Disorders of Plants: Development, visual and analytical diagnosis. Gustav Fischer, Verlag. 741 p

[2] Marschner H. 1995. Mineral Nutrition of Higher Plants. London: Academic Press. 889 p

[3] Shorrocks V. M. 1997. The Occurrence and Correction of Boron Deficiency. Plant Soil. 193, 121-148.

[4] Wójcik. P.. Cieslinski. G., Mika. A. 1999. Apple Yield and Fruit Quality as Influenced by Boron
Applications. Journal of Plant Nutrition, 22(9), 1365-1377.

[5] Paull, J. G., Nable, R. O., Rathjen, A. J. 1992. Physiological and Genetic of The Tolerance of Wheat to High Concentrations of Boron and Implications for Plant Breeding. Plant and Soil, 146, 251-260.

[6] Gupta, U. C. 1976. Boron nutrition of crops. Advances in Agronomy, 31, 273-307.

[7] Bennet, O. L. Mathias, E. L. 1973. Growth and Chemical Composition of Crown Vetch as Affected by Lime, Boron, Soil Source and Temperature Regime. Agronomy Journal, 65, 587-593.

[8] Singh, D.V., Chauhan, RP.S. Charan, R. 1976. Safe and Toxic Limits of Boron for Grain in Sandy Loam and Clay Loam Soils. Indian Journal of Agriculture, 2, 309-316.

[9] Purves, D. McKenzie, E.J.1974. Phytotoxicity due to Boron in Municipal Compost. Plant and Soil, 40, 231-235.

[10] Jones, J.B., Wolf, Jr B., Mills, H.A. 1991. Plant Analysis Handbook. I. Methods of plant analysis and interpretation. Micro-Macro Publishing Inc. 183 Paradise Blvd. Suite 108. Athens Georgia 30607 USA

[11] Wichmann. W. 1992. IFA World Fertilizer Use Manual. International Fertilizer Industry Association, Paris.

[12] Katkat, A. V., Özgümüș, A., Başar, H., Altınel, B. 1994. Bursa Yöresinde Yetiştirilen Şeftali Ağaçlarının Demir, Çinko, Bakır ve Mangan İle Beslenme Durumları. Türk Tarım ve Ormancılık Dergisi, 18, 447-456.

[13] Güleryüz, M., Bolat, L., Pırlak, L., Eşitken., A., Ecişli, S. 1996. Erzincan'da Yetiştirilen Şeftalilerin (Cv. Hasanbey) Beslenme Durumlarının Belirlenmesi Üzerine Araştırmalar. Türk Tarım ve Ormancılık Dergisi, 20, 479-487.

[14] Başar, H., Özgümüș, A., Katkat, A.V. 1997. Evaluation of Nutritional Status for Nitrogen, Phosphorus, Potassium, Calcium, Magnesium by Means of Leaf Analysis in Peach Trees Grown Around Bursa Region. Turkish Journal of Agriculture and Forestry, 21, 257-266.

[15] Sönmez, S., Uz, L, Kaplan, M., Aksoy. T. 1999. Kumluca ve Kale Yörelerinde Yetiștirilen Biberlerin Beslenme Durumlarının Belirlenmesi. 
Turkish Journal of Agriculture and Forestry. 23, 365-373.

[16] Eyüpoğlu F, Kurucu N, Güçdemir İ, Talas S. 2000. Boron status of Central Anatolian. International Conference Sustainable Land Use and Management, 10-13 June 2002, pp. 55-61, Çanakkale, Turkey.

[17] Erdal, İ., Yurdakul, İ., Aydemir, O. 2004. Isparta Yöresi Elma Bahçelerinin Verimlilik Durumları. Türkiye 3. Ulusal Gübre Kongresi, 1061-1070.

[18] Peker, R. M., Erdal, İ. 2006. Isparta Yöresi Elma ve Kiraz Bahçelerinin Bor Beslenme Durumlarının Toprak ve Yaprak Analizleriyle Değerlendirilmesi. Süleyman Demirel Üniversitesi Ziraat Fakültesi Dergisi, 1 (1), 33-40

[19] Kacar. B. 2009. Soil Analysis (second press). Nobel Press. 1387.

[20] Olsen. A. 1954. Estimation of Available Phosphorus in Soils by Extraction with Sodium Bicarbonate. Us Dep. of Agri. Circ. 939. Washington DC. Agronomy Journal, 43, 434-437.

[21] Jackson. M. L. 1967. Soil Chemical Analysis. Prentice Hall of India Private Limited. New Delhi.

[22] Lindsay, W. L., Norvell, W. A. 1969. Development of a DTPA Micronutrient Soil Test. Soil Science Society of American Proceeding 35, 600-602.

[23] Bouyoucos. G. L. 1951. A Recalibration of the Hydrometer for Making Mechanical Analysis of Soil. Agronomy journal, 43 (9), 434-438

[24] Allison. L. E., Moodie, C. D. 1965. Carbonate. In : C.A. Black et al (ed.) Methods of soil analysis. Part 2. Agronomy 9:1379-1400. Am. Soc. of Agron.. Inc.. Madison. Wisconsin. U.S.A.

[25] Walkley, A., Black, I. A. 1934. An Examination of the Degtjareff Method for Determining Soil Organic Matter and a Proposed Modification of the Chromic Acid Titration Method. Soil Science, 37(1), 29-38.

[26] Kacar, B., İnal, A. 2008. Plant Analysis. Nobel Press, $1241 \mathrm{p}$

[27] Keren, R., Bingham, F. T. 1985. Boron in Water, Soils, and Plants. Advanced Soil Science, 1, 229276.

[28] Alpaslan M.. Güneş A.. İnal A. 1998. Deneme Tekniği. A.Ü. Ziraat Fakültesi Yayınları. No: 1501. $437 \mathrm{~s}$.

[29] Anonymous. 2015. www.tuik. gov. tr

[30] Epstain, E., Bloom, A. J. 2005. Mineral Nutritions of Plants: Principles and Perspectives. Secon ed. Sinauer Assoc Inc. Publishers. Sunderland, Massachusetts. 